\author{
Corrigendum: Very Early \\ OPEN ACCESS \\ Approved by: \\ Frontiers Editorial Office \\ Frontiers Media SA, Switzerland \\ *Correspondence: \\ Sara Marinell \\ sara.marinelli@cnr.it \\ ${ }^{\dagger}$ Present address: \\ Michele Nutini, \\ Orphanet Italy, Ospedale Pediatrico \\ Bambino Gesù, \\ IRCCS, Rome, Italy \\ ${ }^{\text {F}}$ These authors have contributed \\ equally to this work \\ ${ }^{\S}$ These authors share \\ senior authorship \\ Specialty section: \\ This article was submitted to \\ Multiple Sclerosis \\ and Neuroimmunology, \\ a section of the journal \\ Frontiers in Immunology \\ Received: 18 March 2021 \\ Accepted: 19 March 2021 \\ Published: 06 April 2021 \\ Citation: \\ Angelini $D F$, De Angelis $F$, Vacca $V$ \\ Piras E, Parisi C, Nutini M, Spalloni A, \\ Pagano F, Longone P, Battistini L, \\ Pavone $F$ and Marinelli S (2021) \\ Corrigendum: Very Early Involvement \\ of Innate Immunity in Peripheral Nerve \\ Degeneration in SOD1-G93A Mice. \\ Front. Immunol. 12:682508. \\ doi: 10.3389/fimmu.2021.682508

\section{Involvement of Innate Immunity in Peripheral Nerve Degeneration in SOD1-G93A Mice} \\ Daniela Francesca Angelini ${ }^{1 \neq}$, Federica De Angelis ${ }^{1,2 \neq}$, Valentina Vacca ${ }^{2 \ddagger}$, \\ Eleonora Piras ${ }^{1}$, Chiara Parisi ${ }^{2}$, Michele Nutini ${ }^{1 \dagger}$, Alida Spalloni ${ }^{1}$, Francesca Pagano ${ }^{2}$, \\ Patrizia Longone $^{1 \S}$, Luca Battistini ${ }^{1 \S}$, Flaminia Pavone ${ }^{2 \S}$ and Sara Marinelli ${ }^{2 *}$ \\ ${ }^{1}$ Neuroimmunology Unit, IRCCS Santa Lucia Foundation, Rome, Italy, ${ }^{2}$ CNR-National Research Council, Institute of \\ Biochemistry and Cell Biology, Rome, Italy \\ Keywords: Peripheral nerve degeneration, demyelination, amyotrophic lateral sclerosis, mast cells, monocytes/ \\ macrophages, pro-inflammatory cytokine, autoimmunity

\section{A Corrigendum on} \\ Very Early Involvement of Innate Immunity in Peripheral Nerve Degeneration in SOD1- \\ G93A Mice \\ Angelini DF, De Angelis F, Vacca V, Piras E, Parisi C, Nutini M, Spalloni A, Pagano F, Longone P, Battistini L, \\ Pavone F and Marinelli S (2020). Front. Immunol. 11:575792. doi: 10.3389/fimmu.2020.575792 \\ In the published article, there was an error regarding the equal contributions label (‡). Valentina \\ Vacca should also have this label. \\ The authors apologize for this error and state that this does not change the scientific conclusions \\ of the article in any way. The original article has been updated. \\ Copyright $\odot 2021$ Angelini, De Angelis, Vacca, Piras, Parisi, Nutini, Spalloni, Pagano, Longone, Battistini, Pavone and Marinelli. \\ This is an open-access article distributed under the terms of the Creative Commons Attribution License (CC BY). The use, \\ distribution or reproduction in other forums is permitted, provided the original author(s) and the copyright owner(s) are credited \\ and that the original publication in this journal is cited, in accordance with accepted academic practice. No use, distribution or \\ reproduction is permitted which does not comply with these terms.
}

